\title{
GAMBARAN EMPATI GENERASI MILLENIAL DI PEKANBARU
}

\author{
Qori'ah Fadhillah \\ Fakultas Psikologi, Universitas Islam Riau, Indonesia \\ e-mail: qoriahfadhillah@gmail.com
}

\begin{abstract}
Empathy is an individual ability to identify and understand about people's feelings, so a person can see and feel other people's feelings from many perspectives without losing control of themselves. The purposes of this research is to know about Empathy of Millenials Generation in Pekanbaru. It was a descriptive analytical statistic that involves 145 participants, which uses disproportionate stratified random sampling technique and Interpresonal Reactivity Index (IRI) scale that contains 20 items. The result shows that Millenial Generation in Pekanbaru have empathy in a medium range or average percentage $31,7 \%$ from 46 participants. There are significant differences between each age range (significancy score $=0,014, p<0.05$ ), the average score in 25-29 years old is the highest than other age range. There are no significant differences of averages empathy score based on gender, spare time, and language. We can conclude that Millenial Generation in Pekanbaru is not good enough in understanding other people's feeling and put themselves up to other people
\end{abstract}

Keywords: empathy, millenials generation, social interaction.

\begin{abstract}
ABSTRAK
Empati adalah kemampuan individu mengidentifikasi dan memahami perasaan orang lain, serta individu dapat melihat dan merasakan suatu kejadian yang dirasakan orang lain dari berbagai prespektif tanpa kehilangan kontrol atas dirinya. Tujuan penelitian ini untuk mengetahui bagaimana Gambaran Empati Pada Generasi Millenial di Pekanbaru. Partisipan penelitian dalam penelitian ini berjumlah 145 orang dengan teknik pengambilan sampel yaitu disproportionate stratified random sampling. Alat ukur yang digunakan dalam penelitian ini adalah skala Interpresonal Reactivity Index (IRI) yang terdiri dari 20 aitem. Analisis yang digunakan yaitu analisis statistik deskriptif. Hasil penelitian adalah generasi millenial di Pekanbaru memiliki empati dalam kategori yang sedang atau rata-rata dengan persentase sebesar $31,7 \%$ sebanyak 46 responden. Hasil penelitian menunjukkan terdapat perbedaan signifikan antar jenjang usia (skor signifikansi $=$ $0,014, p<0.05$ ), dimana skor rata-rata jenjang usia 25-29 tahun lebih tinggi daripada jenjang usia lainnya. Selain itu, tidak ditemukan perbedaan yang signifikan skor rata-rata empati berdasarkan jenis kelamin, kegiatan waktu luang, dan bahasa. Dapat disimpulkan bahwa generasi millenial di Pekanbaru masih kurang dalam memahami perasaan dan memposisikan diri pada posisi orang lain.
\end{abstract}

Kata kunci: empati, generasi milenial, interaksi sosial.

\section{PENDAHULUAN}

Konsep perbedaan generasi terus berkembang dari waktu ke waktu. Perbedaan generasi ini menggunakan kriteria umum, yakni tahun kelahiran serta berbagai peristiwa yang terjadi secara global (Twenge, 2006). Generasi Millenial merupakan terminologi generasi yang saat ini banyak diperbincangkan oleh banyak kalangan di berbagai bidang. Generasi milenial adalah mereka yang lahir dalam rentang tahun 1983 hingga 2001 (Calson, 
2008). Dapat disimpulkan bahwa yang lahir pada tahun 1983 - 2001 atau yang saat ini berusia 18 hingga 36 tahun termasuk dalam generasi milenial.

Berdasarkan penelitian yang dilakukan oleh Higher Education Reserch Institute, menunjukkan bahwa keinginan untuk terlibat di kegiatan lingkungan menurun dari $33 \%$ di generasi Baby Boomers menjadi $21 \%$ di generasi Milenial (BPS, 2018). Salah satu penyebab terjadinya krisis moral pada generasi millenial saat ini ialah mulai menurunnya empati dalam diri individu kaum millenial itu sendiri. Mereka cenderung bersikap individualistis, apatis, kurang bertanggung jawab bahkan acuh tak acuh terhadap orang lain maupun lingkungan sekitar, malas berkomunikasi dan berinteraksi, menurunnya nilai- nilai luhur kemanusiaan serta kemasyarakatan, merupakan fenomena yang menunjukkan terdapat kehampaan nilai sosial dalam kehidupan sehari-hari.

Menurut Aprinus (dalam Ika, 2013) menurunnya budaya empati pada masyarakat Indonesia berdampak pada kekerasan serta konflik yang terjadi. Berbagai usia dan kalangan melakukan aksi yang bertentangan dengan aturan kesusilaan, seperti halnya mencuri, korupsi, penipuan, pemerkosaan atau pelecehan seksual, tawuran, dan bullying. Fenomena yang juga terjadi di Pekanbaru, dimana seorang siswi yang tinggal di Tenayan Raya mendapat tindakan bullying sebagai korban pelecehan seksual oleh teman sekelasnya. Hal ini berakibat pada psikis nya, dan lebih memilih mengurung diri di kamar (Tanjung, 2019). Kejadian ini terjadi karena krisis moral, yaitu menurunnya empati atau bahkan dapat menghilangkan perasaan empati individu kepada sekitarnya.

Mannheim (dalam Putra, 2016) mengatakan bahwa generasi yang lebih muda tidak dapat bersosialisasi dengan sempurna karena adanya celah antara nilai - nilai ideal yang diajarkan oleh generasi yang lebih tua dengan realitas yang dihadapi oleh generasi muda tersebut. Dan lokasi sosial juga memiliki efek yang besar terhadap terbentuknya kesadaran dari individu itu sendiri. Seperti halnya kasus bunuh diri yang terjadi di sebuah pusat perbelanjaan yang ada di Kota Bandar Lampung oleh seorang pemuda. Sangat disayangkan, sikap warga cenderung tak acuh dan bahkan menjadikan aksi tersebut sebagai tontonan serta merekamnya. Bukan berusaha untuk menolong, warga justru menyerukan kepada pemuda tersebut untuk segera melompat (Saumi, 2019).

Berdasarkan penelitian Dolby (2014), menggambarkan reaksi mahasiswa terhadap studi kasus "Toys for Haiti", yang dibuat untuk menumbuhkan empati pada mahasiswanya. Peneliti memberikan sebuah gambaran tentang penurunan empati generasi milenial yang menunjukkan bahwa kebiasaan dalam kehidupan sehari-hari dapat mengubah individu secara substansial terhadap kapasitas empati serta pemahaman mereka. Generasi muda ini memiliki karakteristik yang tidak akan mentoleransi kebodohan, bertindak individualistis, mereka telah mencapai antipati lingkungan dengan menyebabkan situasi konflik berdasarkan keyakinan diri mereka sendiri serta tidak mentolerir adanya pertentangan antara dua hal yang berlawanan atau kontradiksi, terlalu percaya diri dalam keinginan untuk berkarier (Bencsik A., Gabriella, H-C., Tímea, J., 2016).

Rendahnya empati berkorelasi dengan perilaku agresif. Seperti pada pertengahan Oktober tahun 2016 lalu, sosial media diramaikan perihal unggahan yang memperlihatkan rendahnya empati. Sebuah akun sosial media memposting kronologi kejadian saat dua orang perempuan berumur 20 tahunan yang enggan memberikan kursi prioritas kepada seorang kakek yang berdiri di samping perempuan tersebut. Beberapa transportasi publik Jakarta khususnya $\mathrm{KRL}$, menyediakan tempat duduk prioritas yang diperuntukkan bagi anak kecil, perempuan hamil, lansia, dan penyandang disabilitas. Dalam kasus ini empati akan diuji, dan akal sehat akan diukur. Banyak dari anak muda yang tak peduli bahkan menyepelekan hal tersebut (Putri, 2016).

Masyarakat cenderung mengalami penurunan empati dalam interaksi sosial. 
Ketidakmampuan individu dalam melakukan empati menimbulkan perilaku menyimpang, seperti kekerasan (bullying), memperkosa, dan menyiksa (Goleman, 2000). Melalui berita di media massa, sering terjadi kasus-kasus perundungan yang sengaja dipublikasikan oleh pelakunya. Banyaknya kasus perundungan yang didasari tindak kekerasan berimbas buruk kepada korban dan mengakibatkan upaya bunuh diri akibat tindak kekerasan dan perasaan takut, tertekan. Berdasarkan hasil survei yang dilakukan pada tahun 2015 oleh The Global School-Based Health Survey menunjukkan bahwa $20 \%$ siswa-siswi usia 13 sampai 17 tahun di Indonesia menjadi korban perundungan di sekolah dan $32 \%$ siswa-siswi telah mengalami kekerasan fisik (Kementerian Perencanaan Pembangunan Nasional dan Unicef, 2017).

Remaja yang tidak empati akan memunculkan perilaku yang kasar terhadap orang lain yang tidak mereka sukai, dan saat dewasa akan menjadi tidak peduli terhadap kesusahan orang lain (Sejiwa, 2007). Kasus lain seperti kekerasan remaja di Ambon, Maluku terdapat sekelompok wanita muda yang diduga pelajar SMP telah mengeroyok seorang remaja puteri yang tidak berdaya (Patty, 2015). Adapun kasus siswi SMP di kota Pasuruan pada 17 juni 2016 diperkosa secara bergiliran, dimana salah satu pelakunya merupakan siswa kelas dua SMP (Hartik, 2016).

Faktanya, generasi millenial saat ini cenderung memiliki sikap acuh terhadap kondisi orang lain yang ada disekitarnya. Seperti yang terjadi di salah satu SMA Negeri di kota Semarang. Berdasarkan penelitian yang dilakukan oleh Zahro, A., Awalya, A., \& Sri Haratati, M. (2018) mereka menemukan adanya penurunan empati pada siswa kelas XI IPS I dengan presentase sebesar $36,46 \%$. Data tersebut menunjukan bahwa pada kelas tersebut siswa seringkali sulit untuk memahami jalan pikiran dan emosi yang dirasakan oleh temannya. Sejalan dengan hal tersebut ketika dilakukannya observasi di kelas XI IPS I, terdapat salah satu siswa yang memiliki keterbatasan kemampuan fisik dan berkomunikasi, namun siswa yang lain bersikap mengolok bahkan menertawakan siswa tersebut saat berbicara, bahkan tidak ada satupun siswa yang ingin duduk disebelah siswa tersebut. Berdasarkan penelitian Konrath, O'Brien, dan Hsing (2011) menunjukkan penurunan empati pada mahasiswa yang lahir tahun 1980-an hingga 2009 sekitar 40\%, ketimbang mahasiswa yang lahirnya tahun 1970-an hingga awal tahun 1980-an. Dapat disimpulkan bahwa mahasiswa yang lahir pada tahun 1970-1980 memiliki empati yang lebih tinggi dari mahasiswa yang lahir pada tahun 1980-2009. Sejalan dengan penelitian yang dilakukan oleh Fitriyanti (2014) menunjukkkan bahwa perilaku empati mahasiswi di Asrama Putri Nusantara Universitas Negeri Gorontalo masih sangat minim karena berada pada kategori sangat rendah sebesar $56,86 \%$.

Penyebab merosotnya kemampuan berempati sangat kompleks. Lingkungan tempat mereka dibesarkan mempengaruhi kecerdasan berempati. Beberapa faktor sosial yang membentuk karakter berempati secara perlahan mulai menurun. Seperti kurangnya teladan perilaku berempati, pola asuh dan pengawasan yang lemah, serta pendidikan kurang memberikan stimulasi terhadap pertumbuhan empati. Selain itu, generasi millenial secara terus menerus menerima masukan dari luar yang bertentangan dengan norma- norma. Tantangan semakin besar karena pengaruh buruk tersebut muncul dari berbagai sumber yang mudah diakses seperti televisi, film, videogame, dan internet yang memberikan pengaruh buruk bagi kepribadian seseorang karena menyodorkan pelecehan, kekerasan, dan penyiksaan (Borba, 2008).

Menurunnya empati pada masyarakat dapat juga dilihat dari fenomena yang memprihatinkan yang ditemui akhir-akhir ini. Marakya video-video pelecehan bullying, bunuh diri, kecelakaan, serta hoax yang beredar di media sosial, daripada menolong mereka justru berlomba-lomba merekam serta menggunggahya di media sosial. Pada tanggal 6 Juni 2017, beredarnya video seorang wanita muda pengidap sakit mental yang berbelanja 
hampir tanpa busana di sebuah apotek kawasan Mangga Besar, Jakarta Barat (Kompasiana, 2017). Sikap masyarakat inilah yang sangat disayangkan, seharusnya masyarakat yang melihat kejadian tersebut memberikan bantuan seperti memberikan pakaian yang layak lalu membawa ke pihak yang berwajib. Bukan sekedar merekam lalu memviralkan, atau bahkan menertawakannya.

Kebanyakan individu tidak mau mencoba untuk memahami perasaan dan memposisikan diri di posisi orang lain. Hal ini disebabkan karena kultur empati yang sudah hampir punah. Sejumlah pernyataan yang bersifat diskriminatif banyak digunakan oleh masyarakat Indonesia. Seperti mengejek orang lain dengan sebutan pembantu ataupun pekerjaan kasar lainnya. Dikutip dari Sindonews, masyarakat Indonesia dikejutkan dengan peristiwa kerusuhan pembakaran sejumlah gedung publik di Kota Palopo, Sulawesi Selatan oleh massa selesai pemilukada. Kemudian, penyerangan oleh kelompok yang tak dikenal di Lapas Cebongan, Sleman. (Keswara, 2013).

Berdasarkan perkembangan teknologi dan pengaruh kehadiran sosial media telah membawa perubahan bagi kehidupan manusia khususnya perilaku. Dampak perkembangan terknologi tersebut membuat sebagian besar individu kurang memiliki empati, terbukti dengan banyaknya orang yang lebih cepat mengeluarkan gadget untuk mengambil gambar ketika suatu musibah terjadi daripada tanggap menolong. Beberapa kasus dapat dibuktikan dengan beredarnya sebuah video bunuh diri yang dilakukan oleh dua kakak-beradik di Bandung. Video tersebut direkam oleh seseorang dari bawah gedung tempat kejadian. Di dalam video terlihat beberapa orang yang berada disekitar lokasi dengan memegang handphone dan sibuk merekam kejadian tersebut. Jika dibiarkan, akan melahirkan masyarakat Indonesia yang tidak memiliki sikap humanis. (Juliharti, 2017).

Fenomena krisis empati tersebut dibuktikan dengan ungkapan Charyna Ayu Rizkyanti seorang Psikolog dari Universitas Pancasila (UP) pada sindonews (Purnama,
2014) bahwa krisis itu terjadi lantaran rasa empati seseorang terhadap orang lain sudah menurun, bahkan hilang sama sekali. Pembunuhan dapat dilakukan oleh siapapun. Namun yang menjadi kontrol atas tindak agresif tersebut adalah diri sendiri. Seseorang yang tidak memiliki empati akan berpotensi untuk bertindak agresif. Namun saat empati sudah tertanam dalam diri seseorang, maka ia akan terhindar dari tindakan agresif yang merugikan orang lain. Rasa empati ada pada setiap individu, namun seiring berjalannya waktu, rasa itu dapat berkurang bahkan menghilang. Dikutip dari Kompas Pekanbaru - YP (19) seorang remaja di Kecamatan Kandis, Kabupaten Siak, Riau, tega membunuh pacarnya, DS (14). Korban dibunuh, karena menolak diajak berhubungan badan oleh pelaku (Tanjung, 2019).

Hoffman (dalam Sukmawati, 2017) menegaskan bahwa dasar moralitas terdapat dalam empati, karena empati terkait dengan pertimbangan moral saat manusia dihadapkan pada dilema calon korban, yaitu mereka yang sedang dalam kesakitan, bahaya, atau kekurangan. Empati merupakan sesuatu yang sensitif, jujur dan tidak dibuat-buat berdasarkan atas apa yang dialami orang lain. Empati diartikan sebagai perasaan simpati dan perhatian terhadap orang lain, khususnya untuk berbagi pengalaman atau secara tidak langsung merasakan penderitaan orang lain (Asih, Yuli Gusti \& Margaretha Maria Shinta Pratiwi, 2010). Empati sendiri merupakan bagian dari hubungan interperseonal. Perasaan yang muncul ini murni dari hati nurani seseorang, mudah untuk diucapkan namun sulit untuk dilaksanakan.

Menurut Titchener (dalam Taufik, 2012) empati membantu kita memahami fenomena-fenomena yang membingungkan seperti fenomena ilusi visual. Ketika sedang berempati, berarti ia sedang menjalin komunikasi atau diskusi dengan dirinya sendiri, orang lain serta lingkungannya. Proses inilah yang nantinya akan menempatkan ia dalam alam kesadarannya, baik itu kondisi diri sendiri, orang lain juga lingkungan sekitar. 
Sehingga akan menghindari si individu dari ilusi visual yang mungkin akan terjadi dalam interaksinya dengan orang lain dan lingkungan sekitar.

Menurut Hoffman (dalam Taufik, 2012) empati itu muncul dari hasil pengamatan atau tanggapan terhadap orang lain yang sedang mengalami ketidaknyamanan, kemalangan, marah sedih, dalam kondisi membahayakan, dan bentuk-bentuk kondisi distress lainnya. Dari kasus di atas, dapat dilihat bahwa kualitas empati antar teman sebaya sudah mulai berkurang. Teman- teman di kelas yang sebaiknya bahu-membahu saling membantu dan mendukung satu sama lain justru malah membully siswi tersebut. Mungkin tak semua yang seperti itu, namun setengah dari lingkungan sekolah sudah tak bisa ikut merasakan bagaimana jadi diri siswi tersebut.

Eisenberg (dalam Hayi, A., Setyowati, E., dan Djunaedi, 2015) mengatakan bahwa empati merupakan sebuah respon afektif yang berasal dari pemahaman keadaan emosi atau kondisi lain, serta yang mirip dengan perasaan orang lain. Empati dapat mengahantarkan energi positif pada orang lain, terlebih lagi pada orang yang sedang dirundung kesulitan. Berdasarkan penelitian yang dilakukan oleh Viorensika, S., dan Suleeman, J., (2013) ditemukan bahwa mahasiswa psikologi Univeritas Indonesia tingkat awal memiliki empati yang lebih tinggi, yakni angkatan 2011 dan angkatan 2012 sekitar $69,26 \%$, daripada mahasiswa tingkat akhir, yakni angkatan 2009 dan angkatan 2010 sekitar $67,15 \%$.

Allport (dalam Taufik 2012) mendefenisikan empati sebagai perubahan imajinasi seseorang ke dalam pikiran, perasaan, dan perilaku orang lain. Empati murni hasil dari imajinasi si individu tanpa ada campur tangan individu lain. Perasaan yang muncul dari dalam diri yang kemudian diluapkan dalam bentuk tindakan nyata. Pada dasarnya porsi setiap individu berbeda-beda, dapat diukur ataupun ditingkatkan.

Empati berpotensi sebagai motivator psikologis untuk membantu orang lain yang mengalami kesulitan. Sehingga empati dapat didefinisikan sebagai kemampuan untuk merasakan atau membayangkan pengalaman emosional orang lain (Runtuwarow, F. Pasiak, \& R. Ticoalu, 2017). Kemampuan berempati merupakan bagian penting dari perkembangan emosional dan sosial yang mempengaruhi perilaku individu terhadap orang lain serta kualitas hubungan sosial. Sama halnya dengan Wispe (dalam Taufik, 2012) yang mengatakan bahwa empati mengacu pada upaya seseorang untuk memahami pengalaman positif dan negatif dari diri orang lain.

Jadi dapat disimpulkan bahwa empati merupakan kemampuan individu mengidentifikasi dan memahami perasaan orang lain, serta individu dapat melihat dan merasakan suatu kejadian yang dirasakan orang lain dari berbagai prespektif tanpa kehilangan kontrol atas dirinya. Selanjutnya, studi ini dimaksudkan untuk menguji secara empiris gambaran empati generasi milenial di Pekanbaru.

\section{Aspek-Aspek Empati}

Menurut Davis dalam (Nashori, 2008) mengemukakan terdapat empat aspek empati, yaitu :

a. Pengambilan perspektif (perspective taking), yaitu kecenderungan individu dalam mengambil sudut pandang individu lain secara spontan.

b. Imajnasi (fantasy), kemampuan individu untuk mengubah dirinya secara imajinatif dengan karakter-karakter dalam novel, film, dan situasi fiksi lainnya.

c. Perhatian empati (empathic concern), perhatian terhadap kemalangan atau kesulitan yang dialami orang lain.

d. Kecemasan pribadi (personal distress), perasaan tidak nyaman atau cemas dalam menyaksikan kesulitan orang lain.

\section{Faktor-Faktor yang Mempengaruhi Empati :}

Menurut Ickes, dkk (dalam Taufik, 2012) faktor-faktor empati ialah :

a. Jenis kelamin (gender).

Perempuan lebih mudah merasakan kondisi emosional orang lain 
dibandingkan laki-laki dalam kondisikondisi tertentu. Perempuan juga lebih baik dalam memahami pemikiran dan perasaan orang lain daripada laki-laki.

b. Faktor kognitif.

Orang yang memiliki kecerdasan verbal yang tinggi akan dapat berempati lebih baik dibandingkan dengan orang yang rendah tingkat kecerdasannya. Dapat pula dengan mudah mengekspresikan perasan dan pikiran sendiri untuk memahami pikiran serta perasaan orang lain. Selain itu mampu dalam mengungkapkan dalam bentuk bahasa akan membuat target empati mudah dalam berbagi pikiran dan perasaan dengan orang lain.

c. Faktor Sosial

Pengaruh sosial dapat meningkatkan intensitas hubungan dengan orang lain. Empati meningkat ketika orang lain dianggap penting dan menarik. Individuindividu mengarahkan perhatian mereka terhadap isyarat interaksi sosial, termasuk dalam memahami karakteristik vokal.

d. Status Sosial Ekonomi

Orang-orang dengan status sosial ekonomi rendah lebih efektif dalam menerjemahkan emosi-emosi yang sedang dirasakan oleh orang lain, dibandingkan dengan orang-orang satus sosial ekonomi tinggi.

e. Hubungan Dekat

Akurasi empati sangat bagus untuk membangun sebuah hubungan yang baik, jika setiap orang saling mengenal dan memahami satu sama lain maksa setiap hubungan akan berjalan dengan baik pula, maka dunia pun akan menjadi tempat yang indah.

\section{Terbentuknya empati pada Generasi Millenial}

Perubahan empati dapat terjadi sepanjang masa, ditambah lagi dengan adanya perkembangan teknologi yang sangat mempengaruhi gaya hidup seseorang. Schieman dan Van Gundy (dalam Konrath, O'Brien, \& Hsing, 2011) menyatakan adanya hubungan antara empati dengan usia, dimana pengalaman yang dialami seseorang dapat mempengaruhi empatinya. Hal ini memungkinkan seseorang mengalami perubahan tingkat empati karena ia telah mengalami banyak pengalaman.

Sikap empati akan mendorong seseorang untuk peduli terhadap orang lain. Namun, jika berinteraksi dengan orang lain lebih sering melalui media online daripada berinteraksi secara langsung, akan mempengaruhi dinamika interpersonal, khususnya empati (Konrath, O'Brien, \& Hsing, 2011). Sehingga dapat disimpulkan bahwa empati dapat berubah sepanjang masa, karena dipengaruhi oleh zaman serta pengalaman yang dirasakan oleh masing-masing individu.

Menurut Manheim (dalam Putra, 2016) generasi merupakan suatu konstruksi sosial yang didalamnya terdapat sekelompok orang yang memiliki kesamaan umur dan pengalaman historis. Lebih lanjut, Putra (2016) mengatakan bahwa generasi terbanyak saat ini adalah Generasi $Y$ yang disebut generasi millenial atau generasi milenium.

Menurut Carlson (2008), generasi milenial ialah mereka yang terlahir dalam rentang tahun 1983-2001. Jika didasarkan pada Generation Theory yang dicetuskan oleh Karl Mannheim (dalam Badan Pusat Statistik, 2018), generasi milenial merupakan individu yang lahir pada tahun 1980 - 2000. Lebih lanjut, Berkup (2014) menyebutkan bahwa generasi milenial atau yang disebut generasi $Y$ adalah mereka yang lahir antara tahun 1980 sampai dengan 2001. Stafford dan Griffis (2008) juga menyatakan bahwa generasi milenial ialah populasi yang lahir kisaran tahun 1980 - 2000. Sedangkan menurut United States Census Bureau (2015) generasi milenial adalah mereka yang terlahir pada tahun 1982 sampai 2000.

Ali dan Purwandi (2017) mengatakan bahwa generasi millenial merupakan mereka yang lahir pada kisaran tahun 1981-2000. Dimana kaum Millennial terlahir pada dunia modern dengan teknologi canggih yang diperkenalkan publik. Berdasarkan penelitian yang dilakukan oleh Metz (2014) didapatkan hasil bahwa generasi milenial menunjukkan penurunan tingkat empati 
sebesar $48 \%$ dari generasi sebelumnya, karena peningkatan penggunaan teknologi serta penurunan menghabiskan waktu diluar rumah.

Generasi ini banyak menggunakan teknologi komunikasi instan seperti email, SMS, instant messaging dan media sosial seperti facebook dan twitter, dengan kata lain generasi $Y$ adalah generasi yang tumbuh pada era internet booming (Lyons, 2004). Dibanding generasi sebelumnya, generasi millenial memiliki karakter yang unik. Salah satu ciri utama generasi ini ditandai dengan meningkatnya penggunaan dan keakraban dengan komunikasi, teknologi digital, dan media. Secara khusus, kaum Millenial memiliki sifat narsis yang lebih banyak, empati yang lebih rendah, dan kurang peduli terhadap orang lain dan lingkungan (Metz, 2014).

Generasi millenial merupakan generasi yang melibatkan teknologi dalam segala aspek kehidupannya. Menurut Lyons (2004), ciri-ciri dari generasi $Y$ diantaranya memiliki karakteristik yang berbeda pada setiap individu, bergantung dimana ia dibesarkan, strata ekonomi serta status sosial keluarganya, pola komunikasinya sangat terbuka dibanding generasigenerasi sebelumnya, pemakai media sosial yang fanatik dan kehidupannya sangat dipengaruhi oleh perkembangan teknologi, dan lebih terbuka dengan pandangan politik-ekonomi.

Berdasarkan dari hasil penelitian Bencsik \& Machova (2016), terdapat karakteristik lain yang mungkin ada pada generasi milenial diantaranya memiliki keinginan untuk mandiri, tidak menghormati tradisi, mencari bentukbentuk pengetahuan yang baru, sombong/angkuh, soft skill dan EQ yang kurang dihargai, sosialisasi terbalik. Generasi milenial tidak percaya pada informasi yang bersifat satu arah dan lebih mementingkan pengalaman pribadi.

Berdasarkan penjelasan diatas, dapat disimpulkan bahwa generasi milenial adalah individu yang lahir dari tahun 19802000 atau yang sekarang berusia 20-40 tahun. Generasi milenial ialah generasi pertama yang merasakan teknologi, cenderung mencari informasi melalui internet tanpa menyaringnya terlebih dahulu. Generasi milenial tidak dapat dipisahkan dengan teknologi, karena bagi mereka teknologi merupakan bagian dari kehidupan mereka. Sehingga meminimalisir interaksi secara langsung antar sesama yang menjadikan menurunnya empati pada generasi milenial.

\section{METODE PENELITIAN}

Penelitian ini menggunakan pendekatan deskriptif kuantitatif yang bertujuan untuk menjelaskan, meringkaskan berbagai kondisi, situasi, ataupun variabel yang timbul di masyarakat yang menjadi objek penelitian itu berdasarkan apa yang terjadi (Bungin, 2005).

Partisipan penelitian dalam penelitian ini berjumlah 145 orang dengan teknik pengambilan sampel yaitu disproportionate stratified random sampling. Populasi pada penelitian ini berjumlah 324.603 orang generasi milenial yang berusia 20-34 tahun di Pekanbaru (Badan Pusat Statistik Kota Pekanbaru, 2019). Penelitian ini dilakukan dengan membagikan kuisioner yang berisikan skala empati yang diadaptasi dari Rosyadi (2017) terdiri dari 20 butir.

Partisipan dalam penelitian ini diinstruksikan menjawab skala pengukuran dengan pilihan jawaban dari Likert yang terdiri dari skala 4 poin $(4=$ Sangat Setuju sampai dengan 1 = Sangat Tidak Setuju). Kuisioner disebarkan melalui link menggunakan platform whatsapp dan instagram. Setelah responden mengisi kuisioner selanjutnya peneliti melakukan editing, coding, tabulating, cleaning dan saving lalu dilakukan analisa data menggunakan metode deskriptif kuantitatif yang hasilnya dipaparkan dalam bentuk tabel distribusi frekuensi.

\section{HASIL DAN PEMBAHASAN}

Berdasarkan penelitian yang telah dilakukan, peneliti mendapatkan jumlah respon identitas subjek yang berjumlah 145 orang. Data demografi yang terkumpul yaitu jenis kelamin, usia, kegiatan waktu luang, dan bahasa. 
Tabel 1 Kategorisasi Skor Gambaran Empati Generasi Milenial Pekanbaru

\begin{tabular}{|c|c|c|c|}
\hline Kategori & Skor & Jumlah & Presentase \\
\hline $\begin{array}{l}\text { Sangat } \\
\text { tinggi }\end{array}$ & $70,73 \geq X$ & 11 & $7,6 \%$ \\
\hline Tinggi & $\begin{array}{c}64,95 \leq \\
70,73\end{array}$ & 39 & $26,9 \%$ \\
\hline Sedang & $\begin{array}{c}59,52 \leq \\
64,95\end{array}$ & 46 & $31,7 \%$ \\
\hline Rendah & $54,1 \leq 59,52$ & 41 & $28,3 \%$ \\
\hline $\begin{array}{l}\text { Sangat } \\
\text { rendah }\end{array}$ & $x \leq 54,1$ & 8 & $5,5 \%$ \\
\hline Total & & 145 & $100 \%$ \\
\hline
\end{tabular}

Berdasarkan tabel di atas sebanyak 145 orang dari generasi milenial di Pekanbaru, memiliki persentase empati yang beragam. Untuk kategori empati sangat tinggi yaitu 11 orang dengan persentase 7,6\%. Kategori empati tinggi yaitu 39 orang dengan persentase 26,9\%. Kategori empati sedang yaitu 46 orang dengan persentase $31,7 \%$. Kategori empati rendah yaitu 41 orang dengan persentase $28,3 \%$. Terakhir, kategori empati sangat rendah yaitu 8 orang dengan persentase $5,5 \%$. Dapat disimpulkan bahwa generasi milenial di Pekanbaru memiliki tingkat empati yang tergolong sedang yaitu $31,7 \%$ sebanyak 46 orang.

Tabel 2 Kategorisasi Skor Empati Berdasarkan Jenis Kelamin pada Generasi Milenial Pekanbaru

\begin{tabular}{l|rr|rr|l|r}
\hline \multirow{2}{*}{ Kategori } & \multicolumn{2}{|c|}{ Perempuan } & \multicolumn{2}{c|}{ Laki-laki } & \multicolumn{2}{|c}{ Total } \\
\cline { 2 - 7 } & F & $\%$ & \multicolumn{2}{|c|}{ F } & $\%$ & \multicolumn{2}{|l}{ F } & \multicolumn{2}{c}{$\%$} \\
\hline $\begin{array}{l}\text { Sangat } \\
\text { tinggi }\end{array}$ & 9 & $6,2 \%$ & 2 & $1,4 \%$ & 11 & $7,6 \%$
\end{tabular}

\begin{tabular}{l|cc|cc|c|c} 
Tinggi & 25 & $17,2 \%$ & 14 & $9,7 \%$ & 39 & $\begin{array}{c}26,9 \\
\%\end{array}$ \\
$\begin{array}{l}\text { Sedan } \\
\text { g }\end{array}$ & 29 & $20 \%$ & 17 & $11,7 \%$ & 46 & $\begin{array}{c}31,7 \\
\%\end{array}$ \\
$\begin{array}{l}\text { Renda } \\
\text { h }\end{array}$ & 24 & $16,5 \%$ & 17 & $11,7 \%$ & 41 & $\begin{array}{c}28,3 \\
\%\end{array}$ \\
$\begin{array}{l}\text { Sangat } \\
\text { rendah }\end{array}$ & 5 & $3,4 \%$ & 3 & $2,1 \%$ & 8 & $5,5 \%$ \\
\hline Total & 92 & $63,4 \%$ & $\begin{array}{l}5 \\
3\end{array}$ & $\begin{array}{l}36,6 \\
\%\end{array}$ & $\begin{array}{c}14 \\
5\end{array}$ & $100 \%$ \\
\hline
\end{tabular}

Tabel diatas menunjukkan persentase empati generasi milenial Pekanbaru berdasarkan jenis kelamin. Pada kategori empati sangat rendah untuk perempuan terdapat sebanyak 5 orang dengan persentase $3,4 \%$ dan pada laki-laki yaitu 3 orang dengan persentase $2,1 \%$. Kategori empati rendah pada perempuan yaitu 24 orang dengan persentase $16,5 \%$ dan pada laki-laki yaitu 17 orang dengan persentase $11,7 \%$. Kategori empati sedang pada perempuan yaitu 29 orang dengan persentase $20 \%$ dan pada laki-laki yaitu 17 orang dengan persentase $11,7 \%$. Kategori empati tinggi pada perempuan terdapat 25 orang dengan persentase $17,2 \%$ dan pada laki-laki yaitu 14 orang dengan persentase $9,7 \%$. Terakhir, kategori empati sangat tinggi pada perempuan terdapat 9 orang dengan persentase $6,2 \%$ dan pada laki-laki yaitu 2 orang dengan persentase 1,4\%. Dapat disimpulkan bahwa persentase empati generasi milenial Pekanbaru berdasarkan jenis kelamin, subjek yang dominan ialah perempuan berada pada kategori empati sedang sebesar $20 \%$.

Tabel 3 Kategorisasi Skor Empati Berdasarkan Usia pada Generasi Milenial Pekanbaru

\begin{tabular}{|c|c|c|c|c|c|c|c|c|}
\hline \multirow[t]{3}{*}{ Kategorisasi } & \multicolumn{8}{|c|}{ Usia } \\
\hline & \multicolumn{2}{|c|}{ 20-24 Tahun } & \multicolumn{2}{|c|}{ 25-29 Tahun } & \multicolumn{2}{|r|}{$\begin{array}{l}\text { 30-34 } \\
\text { Tahun }\end{array}$} & \multicolumn{2}{|c|}{ Total } \\
\hline & $\mathbf{F}$ & $\%$ & $\mathbf{F}$ & $\%$ & $\mathbf{F}$ & $\%$ & $F$ & $\%$ \\
\hline $\begin{array}{l}\text { Sangat } \\
\text { tinggi }\end{array}$ & 4 & $2,8 \%$ & 7 & $4,8 \%$ & & $0 \%$ & 11 & $7,6 \%$ \\
\hline Tinggi & 22 & $15,2 \%$ & 15 & $10,3 \%$ & & $2,1 \%$ & 40 & $27,6 \%$ \\
\hline Sedang & 35 & $24,1 \%$ & 7 & $4,8 \%$ & & $2,1 \%$ & 45 & $31,0 \%$ \\
\hline
\end{tabular}




\begin{tabular}{c|cc|cc|cc|cc} 
Rendah & 28 & $19,3 \%$ & 7 & $4,8 \%$ & 6 & $4,2 \%$ & 41 & $28,3 \%$ \\
$\begin{array}{l}\text { Sangat } \\
\text { rendah }\end{array}$ & 7 & $4,8 \%$ & 1 & $0,7 \%$ & 0 & $0 \%$ & 8 & $5,5 \%$ \\
\hline Total & 96 & $66,2 \%$ & 37 & $25,5 \%$ & 12 & $8,3 \%$ & 145 & $100 \%$ \\
\hline
\end{tabular}

Tabel diatas menunjukkan empati generasi milenial Pekanbaru berdasarkan usia. Pada kategori empati sangat rendah untuk usia 20-24 tahun terdapat sebanyak 7 orang dengan persentase sebesar $2,8 \%$, dan untuk usia 25-29 tahun sebanyak 1 orang dengan persentase sebesar $0,7 \%$. Pada kategori empati rendah untuk usia 20-24 tahun sebanyak 28 orang dengan persentase sebesar $19,3 \%$, untuk usia 25-29 tahun sebanyak 7 orang dengan persentase sebesar $4,8 \%$ dan untuk usia 30-34 tahun sebanyak 6 orang dengan persentase sebesar $4,2 \%$. Pada kategori empati sedang untuk usia 20-24 tahun sebanyak 35 orang dengan persentase sebesar $24,1 \%$, untuk usia 25 29 tahun sebanyak 7 orang dengan persentase sebesar $4,8 \%$, dan untuk usia
30-34 tahun sebanyak 3 orang dengan persentase sebesar $2,1 \%$. Pada kategori empati tinggi untuk usia 20-24 tahun sebanyak 22 orang dengan persentase sebesar $15,2 \%$, untuk usia $25-29$ tahun sebanyak 15 orang dengan persentase sebesar $10,3 \%$, dan untuk usia $30-34$ tahun sebanyak 3 orang dengan persentase sebesar $2,1 \%$. Pada kategori empati sangat tinggi untuk usia 20-24 tahun sebanyak 4 orang dengan persentase sebesar $2,8 \%$, dan untuk usia 25-29 tahun sebanyak 7 orang dengan persentase sebesar $4,8 \%$. Dapat disimpulkan bahwa persentase empati generasi millenial Pekanbaru berdasarkan usia, responden yang dominan ialah pada usia 20-24 tahun berada pada kategori empati yang sedang sebesar $24,1 \%$.

Tabel 4 Kategorisasi Skor Empati Berdasarkan Waktu Luang pada Generasi Milenial Pekanbaru

\begin{tabular}{|c|c|c|c|c|c|c|}
\hline \multirow[t]{2}{*}{ Kategorisasi } & \multicolumn{2}{|c|}{$\begin{array}{l}\text { Berkumpul/bermain sama } \\
\text { teman }\end{array}$} & \multicolumn{2}{|c|}{ Bermain sosial media } & \multicolumn{2}{|l|}{ Total } \\
\hline & $\mathbf{F}$ & $\%$ & $\mathbf{F}$ & $\%$ & $\mathbf{F}$ & $\%$ \\
\hline Sangat tinggi & 9 & $6,2 \%$ & 2 & $1,4 \%$ & 11 & $7,6 \%$ \\
\hline Tinggi & 36 & $24,8 \%$ & 3 & $2,1 \%$ & 39 & $26,9 \%$ \\
\hline Sedang & 33 & $22,8 \%$ & 13 & $9,0 \%$ & 46 & $31,8 \%$ \\
\hline Rendah & 36 & $24,8 \%$ & 5 & $3,4 \%$ & 41 & $28,2 \%$ \\
\hline $\begin{array}{l}\text { Sangat } \\
\text { rendah }\end{array}$ & 4 & $2,8 \%$ & 4 & $2,8 \%$ & 8 & $5,6 \%$ \\
\hline Total & 118 & $81,4 \%$ & 27 & $18,6 \%$ & 145 & $100 \%$ \\
\hline
\end{tabular}

Tabel diatas menunjukkan persentase empati generasi milenial Pekanbaru berdasarkan kegiatan waktu luang. Pada kategori empati sangat rendah untuk kegiatan berkumpul/bermain bersama teman terdapat sebanyak 4 orang dengan persentase $2,8 \%$, dan pada kegiatan bermain sosial media yaitu 4 orang dengan persentase $2,8 \%$. Kategori empati rendah pada kegiatan berkumpul/bermain bersama teman terdapat sebanyak 36 orang dengan persentase $24,8 \%$, dan pada kegiatan bermain sosial media yaitu 5 orang dengan persentase $3,4 \%$. 
Kategori empati sedang pada kegiatan berkumpul/bermain bersama teman terdapat sebanyak 33 orang dengan persentase $22,8 \%$, dan pada kegiatan bermain sosial media yaitu 13 orang dengan persentase 9,0\%. Kategori empati tinggi pada kegiatan berkumpul/bermain bersama teman terdapat sebanyak 36 orang dengan persentase $24,8 \%$, dan pada kegiatan bermain sosial media yaitu 3 orang dengan persentase 2,1\%. Terakhir, kategori empati sangat tinggi pada kegiatan berkumpul/bermain bersama teman terdapat sebanyak 9 orang dengan persentase $6,2 \%$, dan pada kegiatan bermain sosial media yaitu dua orang dengan persentase 1,4\%. Dapat disimpulkan bahwa persentase empati generasi milenial Pekanbaru berdasarkan waktu luang, responden yang dominan ialah responden yang menghabiskan waktu luangnya dengan berkumpul/bermain bersama teman yang berada pada kategori empati tinggi sebesar $24,8 \%$.

\section{Tabel 5 Kategorisasi Skor Empati Berdasarkan Bahasa sehari-hari pada Generasi Milenial Pekanbaru}

\begin{tabular}{|c|c|c|c|c|c|c|c|c|}
\hline \multirow{3}{*}{$\begin{array}{c}\text { Kategori } \\
\text { sasi }\end{array}$} & \multicolumn{8}{|c|}{ Bahasa } \\
\hline & \multicolumn{2}{|c|}{ Indonesia } & \multicolumn{2}{|c|}{ Melayu } & Minang & Other & \multicolumn{2}{|c|}{ Total } \\
\hline & $\mathbf{F}$ & $\%$ & $\mathbf{F}$ & $\%$ & $\mathrm{~F} \quad \%$ & F $\%$ & $\mathbf{F}$ & $\%$ \\
\hline $\begin{array}{c}\text { Sangat } \\
\text { tinggi }\end{array}$ & 11 & $7,6 \%$ & 0 & $0 \%$ & $0 \quad 0 \%$ & $0 \quad 0 \%$ & 11 & $7,6 \%$ \\
\hline Tinggi & 39 & $26,9 \%$ & 0 & $0 \%$ & $0 \quad 0 \%$ & $0 \quad 0 \%$ & 39 & $\begin{array}{c}26,9 \\
\%\end{array}$ \\
\hline Sedang & 43 & $29,6 \%$ & 0 & $0 \%$ & $32,1 \%$ & $0 \quad 0 \%$ & 46 & $\begin{array}{c}31,7 \\
\%\end{array}$ \\
\hline Rendah & 40 & $27,6 \%$ & 0 & $0 \%$ & $10,7 \%$ & $00 \%$ & 41 & $\begin{array}{c}28,3 \\
\%\end{array}$ \\
\hline $\begin{array}{l}\text { Sangat } \\
\text { rendah }\end{array}$ & 8 & $5,5 \%$ & 0 & $0 \%$ & $0 \quad 0 \%$ & $0 \quad 0 \%$ & 8 & $5,5 \%$ \\
\hline Total & 141 & $97,2 \%$ & 0 & $0 \%$ & $42,8 \%$ & $00 \%$ & 145 & $100 \%$ \\
\hline
\end{tabular}

Tabel diatas menunjukkan persentase empati generasi milenial Pekanbaru berdasarkan bahasa yang digunakan dalam kehidupan sehari-hari. Mayoritas responden menggunakan bahasa
Indonesia dalam kehidupan sehariharinya, dan minoritas menggunakan bahasa minang. Pada kategori empati sangat rendah untuk bahasa Indonesia terdapat sebanyak 8 orang dengan persentase $5,5 \%$. Kategori empati rendah pada bahasa Indonesia terdapat sebanyak 40 orang dengan persentase $27,6 \%$, dan pada bahasa minang yaitu 1 orang dengan persentase $0,7 \%$. Kategori empati sedang pada bahasa Indonesia terdapat sebanyak 43 orang dengan persentase $29,6 \%$, dan pada bahasa minang yaitu 3 orang dengan persentase $2,1 \%$. Kategori empati tinggi pada bahasa Indonesia terdapat sebanyak 39 orang dengan persentase $26,9 \%$. Terakhir, kategori empati sangat tinggi pada bahasa Indonesia terdapat sebanyak 11 orang dengan persentase $7,6 \%$. Dapat disimpulkan bahwa persentase empati generasi millenial Pekanbaru berdasarkan bahasa yang digunakan dalam kehidupan sehari-hari, responden yang dominan ialah responden yang menggunakan bahasa Indonesia yang berada pada kategori empati sedang sebesar $26,9 \%$.

Selanjutnya, setelah melihat gambaran skor skala empati, kemudian dilakukan perhitungan lebih lanjut menggunakan teknik Independent Sample t-Test untuk melihat perbedaan antar jenis kelamin dan kegiatan waktu luang dan menggunakan teknik One-Way ANOVA untuk melihat perbedaan antar jenjang usia dan penggunaan bahasa pada setiap komponen skala empati. Berikut adalah hasil uji beda atas skor rata-rata keseluruhan antara responden perempuan dan laki-laki:

Table 6 Hasil uji beda antar jenis kelamin

\begin{tabular}{ccc}
\hline $\mathbf{T}$ & $\mathbf{d F}$ & Sig. (2-tailed) \\
\hline 1,580 & 143 & 0.116
\end{tabular}

Table 7 Hasil uji beda jenjang usia

\begin{tabular}{llll}
\hline Mean square & F & dF & Sig. \\
\hline Between groups & 4.404 & 2 & 0.014
\end{tabular}

Within groups 
Table 8 Hasil uji beda kegiatan waktu luang

\begin{tabular}{lll}
\hline $\mathbf{T}$ & $\mathrm{dF}$ & Sig. (2-tailed) \\
\hline $\mathbf{0 . 9 5 7}$ & 143 & 0.340 \\
\hline
\end{tabular}

Table 9 Hasil uji beda bahasa

\begin{tabular}{|c|c|c|c|c|}
\hline & an square & $F$ & dF & Sig. \\
\hline $\begin{array}{l}\text { Between } \\
\text { groups }\end{array}$ & 0.966 & 0.033 & 1 & 0.857 \\
\hline $\begin{array}{l}\text { Within } \\
\text { groups }\end{array}$ & 29.602 & & 143 & \\
\hline
\end{tabular}

\section{PEMBAHASAN}

Berdasarkan hasil penelitian yang dilakukan peneliti dari 145 sampel pada generasi millenial di Pekanbaru, dengan menggunakan skala empati yang terdiri dari 20 pernyataan. Usia minimal subjek 20 tahun, sedangkan usia maksimal subjek 34 tahun. Diperoleh hasil bahwa sebanyak 145 orang dari generasi milenial di Pekanbaru memiliki tingkat empati yang berbeda-beda, yakni sebanyak 8 orang atau $5,5 \%$ memiliki empati yang sangat rendah. Sebanyak 41 orang atau $28,3 \%$ memiliki empati yang rendah. Sebanyak 46 orang atau $31,7 \%$ memiliki empati pada kategori sedang. Sebanyak 39 orang atau $26,9 \%$ memiliki empati yang tinggi. Dan untuk kategori sangat tinggi terdapat 11 orang atau $7,6 \%$. Dengan demikian, hal ini menunjukkan bahwa kategori empati pada generasi milenial di Pekanbaru termasuk dalam kategori yang sedang atau rata-rata artinya tidak terlalu tinggi dan tidak pula terlalu rendah dengan persentase sebesar $31,7 \%$.

Hasil ini menjelaskan bahwa empati generasi milenial Pekanbaru masih dalam tingkatan sedang atau rata-rata. Hal ini diperkuat dengan hasil penelitian Arumi, dkk (2017) yang menunjukkan bahwa mahasiswa Fakultas Psikologi Universitas Bhayangkara Jakarta Raya mempunyai empati yang berada pada kategori sedang menuju tinggi dengan skor rata- rata sebesar 63,8321. Sejalan dengan hasil penelitian Yusra, dkk. (2015) bahwasannya empati dasar mahasiswa BK FIP UNJ angkatan 2011 masuk dalam kategori sedang, sebanyak 50 orang mahasiswa $(66,67 \%)$.

Pada penelitian yang dilakukan oleh Konrath, O'Brien, dan Hsing (2011) menunjukkan adanya penurunan empati pada mahasiswa yang lahir tahun 1980-an hingga 2009 sekitar 40\%, dibandngkan dengan mahasiswa yang lahirnya pada tahun 1970-an hingga awal tahun 1980-an. Sejalan dengan hasil penelitian Metz (2014) bahwasanya generasi milenial menunjukkan adanya penurunan tingkat empati sebesar $48 \%$ dari generasi sebelumnya. Sehingga dapat disimpulkan bahwa mahasiswa yang lahir pada tahun 1970-1980 memiliki empati yang lebih tinggi daripada mahasiswa yang lahir pada tahun 1980-2009. Penelitian yang dilakukan oleh Gustini (2017) mengidentifikasikan bahwa perilaku empati mahasiswa di Indonesia mengalami penurunan, ia juga mengemukakan bahwa mahasiswa saat ini cenderung bersikap individualistik, lunturnya nilai-nilai luhur kemanusiaan dan kemasyarakatan dari kehidupan, dan cenderung apatis.

Hasil penelitian lain yang dilakukan oleh Anisa, Martina, dan Mariyono (2013) menunjukkan bahwa nilai rata - rata kemampuan empati mahasiswa PSIK FK UGM idalah sebesar 113,26. Menurut Wispe (dalam Taufik, 2012) empati mengacu pada upaya seseorang untuk memahami pengalaman positif dan negatif dari diri orang lain. Terdapat sebuah proses yang mendalam atau proses kita masuk ke dalam diri orang lain secara mendalam. Sejalan dengan hasil penelitian yang dilakukan oleh Butarbutar dan Achmat (2018) menunjukkan bahwa empati perawat dalam memeberikan asuhan keperawatan di ruang rawat inap Rindu A dan Rindu B RSUP H. Adam Malik Medan mayoritas berada pada kategori baik (sedang) sebesar 87,9\%.

Dilihat berdasarkan kategori jenis kelamin empati generasi milenial Pekanbaru berada pada kategori sedang yang didominasi oleh perempuan dengan persentase sebesar $20 \%$, sedangkan lakilaki sebesar $11,7 \%$. Hasil penelitian ini berdasarkan jenis kelamin menunjukkan bahwa rata-rata nilai skor empati 
mahasiswa perempuan lebih tinggi dari pada mahasiwa laki-laki yaitu sebesar 62,77. Kondisi ini menunjukkan bahwa empati perempuan lebih tinggi dibandingkan laki-laki meskipun tidak menunjukkan perbedaan yang signifikan. Dalam penelitian yang dilakukan oleh Nugroho, Taufik, \& George (2016) mengidentifikasi bahwa mahasiswa perempuan kedokteran unversitas sam ratulangi lebih tinggi daripada mahasiswa laki-laki sebesar 40,7\%. Hasil penelitian lain yang dilakukan oleh Listiyandini, dkk (2017) menunjukkan bahwa mahasiswa kedokteran laki-laki memiliki empati lebih rendah dibandingkan mahasiswa kedokteran perempuan.

Sejalan dengan hasil penelitian yang dilakukan oleh Wardhani (2018) yang menunjukkan terdapat perbedaan empati yang ditinjau dari jenis kelamin, dimana perempuan memiliki tingkat empati yang lebih tinggi dibandingkan laki-laki. Hasil penelitian lain yang dilakukan oleh Aulia (2019) didapatkan nilai rata-rata empati perempuan lebih besar dibandingkan nilai rata-rata empati laki-laki yaitu sebesar 62,65 .

Dalam penelitian yang dilakukan oleh Gustini (2017) menunjukkan bahwa empati kultural mahasiswa berdasarkan jenis kelamin didominasi oleh mahasiswa perempuan $(65 \%)$ yang berkategori sedang, hanya saja dengan persentase yang tidak jauh beda dengan mahasiswa laki-laki (58\%). Di sisi lain, perempuan juga lebih mudah dalam mengekspresikan perasaan terhadap orang lain, baik itu melalui kata-kata maupun perbuatan. Hal ini sesuai dengan pendapat Koestner (dalam Arumi, 2017) bahwa empati merupakan ciri khas wanita yang lebih peka terhadap emosi orang lain dan lebih mampu dalam mengungkapkan emosinya dibandingkan laki-laki. Selanjutnya, ketidak seimbangan jumlah partisipan perempuan dengan partisipan laki-laki yang diduga menjadi salah satu alasan mengapa perbedaan diantara keduanya tidak muncul dalam semua dimensi empati. Dimana partisipan perempuan berjumlah lebih banyak dari partisipan laki-laki, yakni untuk perempuan terdapat 92 partisipan sedangkan laki-laki 53 partsipan.

Berdasarkan kategori usia, empati generasi milenial Pekanbaru berada pada kategori sedang yang didominasi oleh partisipan dengan usia 20-24 tahun yang memiliki persentase sebesar $24,1 \%$. Hasil penelitian ini berdasarkan kategori usia menunjukkan bahwa rata-rata nilai skor empati 25-29 tahun lebih tinggi dari kategori usia yang lainnya yaitu sebesar 64,43 . Artinya, semakin bertambah usia maka akan semakin meningkat pula empatinya. Hal ini diperkuat dengan penelitian yang dilakukan oleh Etikasari (2017) bahwa hampir seluruh mahasiswa berumur 21-24 tahun sebanyak 74 mahasiswa $(97,4 \%)$ berada dalam tahap usia dewasa awal yang cenderung memiliki egoisme yang tinggi mengingat kebutuhan akan aktualisasi diri. Yang membuat mahasiswa lebih fokus untuk menjadikan dirinya terlihat hebat oleh teman-temannya tanpa perduli dengan kondisi teman-teman di sekitarnya. Arnet (2006) mendeskripsikan terdapat lima ciri individu memasuki tahap dewasa awal dan salah satunya adalah self- focused, yakni mahasiswa akan cenderung terfokus pada diri sendiri daripada kondisi lingkungan sekitarnya. Dalam studi penelitian yang dilakukan oleh Arumi (2017) menyatakan bahwa mahasiswa kelompok usia 20-24 tahun memiliki empati dalam kategori sedang yang persentase empatinya lebih tinggi daripada kelompok usia 25-29 tahun dan kelompok usia diatas 30 tahun.

Koestner (dalam Arumi, 2017) mengatakan bahwa semakin tua usia seseorang akan semakin baik pula kemampuan empatinya, hal ini disebabkan adanya penambahan pemahaman perspektif individu seiring bertambahnya usia. Hanya saja hal tersebut tidak begitu terlihat dari hasil penelitian ini. Dari hasil perbadingan tingkatan usia, tidak ditemukan perbedaan yang signifikan. Hal ini dapat disebabkan karena skor cenderung merata pada setiap kategori tingkatan usia, yaitu berada pada kategori sedang. Ketidak seimbangan ini dikarenakan partisipan dalam dalam 
penelitian ini didominasi oleh yang berusia 20-an tahun.

Dilihat dari kategori berdasarkan kegiatan waktu luang yang dilakukan responden, mayoritas responden mengisi waktu luangnya dengan berkumpul/bermain bersama temannya dengan persentase sebesar $24,8 \%$ yang berada pada kategori tinggi. Hasil penelitian ini berdasarkan kegiatan waktu luang menunjukkan bahwa rata-rata nilai skor empati yang memilih untuk berkumpul bersama teman lebih tinggi dari yang menghabisan waktu dengan bermain sosial media yaitu 62,44. Kondisi ini menunjukkan bahwa empati responden yang memilih untuk berkumpul bersama teman dalam mengisi waktu luangnya lebih tinggi meskipun tidak menunjukkan perbedaan yang signifikan. Hal ini sejalan dengan penelitian yang dilakukan oleh Etika (2017) yang mengidentifikasi bahwa sebagian besar dari responden menghabiskan waktu luang dengan berkumpul bersama temn sebesar 41 mahasiswa $(53,9 \%)$. Menurut Baron dan Byrne (2005) empati termasuk kemampuan untuk merasakan keadaan emosional orang lain, merasa simpatik dan mencoba untuk menyelesaikan, serta mengambil perspektif orang lain. Dengan merasakan kondisi emosional orang lain, maka individu bisa membina hubungan yang baik dengan orang lain. Hal ini didukung hasil penelitian yang dilakukan oleh Astuti (2014) bahwa adanya hubungan signifikan antara empati dengan perilaku prososial yang ditunjukkan dengan hasil koefisien korelasi $(r)$ sebesar 0,596 dengan $p$ sebesar $0,000(p<0,01)$.

Peneliti berpendapat bahwa seringnya bersosialisasi dengan orang lain, akan menjadikan individu tersebut dapat mengendalikan ego dan empatinya pun akan tumbuh semakin kuat pada permasalahan orang. Meski terjadi sosialisasi, jika hanya pada lingkungan teman-teman sekelompoknya saja maka empati hanya akan terjadi pada sekelompok bermain itu saja. Dengan begitu, individu akan cenderung apatis dengan permasalahan diluar kelompok bermainnya memiliko anggapan bahwa tidak berkewajiban untuk perduli dengan permasalahan orang lain. Pernyataan tersebut senada dengan pendapat Staub (Tri Dayakisni \& Hudaniah, 2009) bahwa individu yang sering berinteraksi dengan orang lain akan cenderung lebih banyak bertindak prososial dibanding dengan individu yang selalu menyendiri. Pernyataan lain dikemukakan oleh Hoffman (2001) bahwa sosialisasi termasuk dalam salah satu faktor yang mempengaruhi empati seseorang. Sosialisasi menjadi dasar dalam berempati, karena dapat melahirkan sikap empati pada seseorang.

Dilihat dari kategori berdasarkan bahasa yang digunakan dalam kehidupan sehari-hari mayoritas menggunakan bahasa Indonesia sebesar 141 responden $(97,2)$ dan minoritas mengunakan bahasa minang sebesar 4 responden $(2,8 \%)$ yang berada pada kategori sedang. Hasil penelitian ini berdasarkan bahasa yang digunakan menunjukkan bahwa rata-rata nilai skor empati yang menggunakan Bahasa Indonesia lebih tinggi dari bahasa yang lainnya yaitu sebesar 62,25 . Kondisi ini menunjukkan bahwa empati responden yang menggunakan Bahasa Indonesia dalam berkomunikasi lebih tinggi meskipun tidak menunjukkan perbedaan yang signifikan. Pengungkapan empati dipengaruhi oleh komunikasi (bahasa) yang digunakan individu. Adanya perbedaan bahasa dalam berkomunikasi akan menjadi hambatan dalam proses empati. Hal ini senda dengan pendapat Burgon \& Huffner (2002) bahwa komunikasi interpersonal merupakan komunikasi yang dilakukan kepada pihak lain untuk mendapatkan umpan balik secara langsung maupun melalui media. Dengan adanya komunikasi seseorang dapat berbagi pengalaman yang akan menumbuhkan simpati dan empati.

Peneliti berpendapat bahwa keragaman bahasa yang digunakan dalam komunikasi dapat menyulitkan interaksi antar individu. Hal ini didukung dengan penelitian yang dilakukan oleh Etikasari (2017) bahwa responden memiliki keseragaman bahasa yaitu bahasa Jawa sebesar 43 mahasiswa $(56,6 \%)$. Hal ini mengidentifikasi bahwa 
dengan keseragaman bahasa yang dapat dimengerti satu sama lain, akan mempermudah proses komunikasi sehingga umpan balik yang diharapkan ialah sikap empati dari pengalaman yang dibagikan.

Berdasarkan uraian di atas dapat disimpulkan bahwa empati generasi millenial di Pekanbaru termasuk dalam kategori sedang. Dengan skor empati tertinggi adalah responden perempuan, berdasarkan usia yang tertinggi empatinya ialah partisipan dengan usia 20-24 tahun berada pada kategori sedang. Berdasarkan kegiatan waktu luang yang dilakukan emparti tertinggi ialah responden yag berkegiatan berkumpul/bermain bersama teman dan untuk penggunaan bahasa sehari-hari mayoritas menggunakan bahasa Indonesia dari 145 responden generasi milenial di Pekanbaru. Namun tidak terdapat perbedaan yang signifikan dari masing- masing skor empati antara jenis kelamin, kegiatan waktu luang, dan bahasa.

\section{SIMPULAN}

Berdasarkan hasil penelitian dan pembahasan yang telah dilakukan, dapat ditarik kesimpulan sebagai berikut:

1. Gambaran empati pada generasi millenial di Pekanbaru termasuk dalam kategori yang sedang atau rata-rata, artinya tidak terlalu tinggi dan tidak terlalu rendah dengan persentase sebesar $31,7 \%$, yang berarti secara umum generasi millenial di pekanbaru masih kurang dalam memahami perasaan dan memposisikan diri pada posisi orang lain.

2. Berdasarkan jenis kelamin, penelitian ini menyatakan bahwa jenis kelamin perempuan lebih mendominasi yang berada pada kategori sedang yang didominasi oleh perempuan dengan persentase sebesar $20 \%$. Kondisi ini menunjukkan bahwa empati perempuan lebih tinggi dibandingkan laki-laki dengan skor rata-rata 62,77 meskipun tidak menunjukkan perbedaan yang begitu signifikan, bahwasannya jenis kelamin tidak mempengaruhi empati seseorang. Dijelaskan karena perempuan lebih lebih mudah dalam mengekspresikan perasaan terhadap orang lain, baik itu melalui perkataan maupun perbuatan dibanding laki-laki.

3. Berdasarkan rentang usia, penelitian ini menyatakan bahwa responden yang berusia 20-24 tahun yang paling dominan, berada pada kategori sedang dengan persentase 24,1\%. Hasil penelitian ini berdasarkan kategori usia menunjukkan bahwa rata-rata nilai skor empati 25-29 tahun lebih tinggi dari kategori usia yang lainnya yaitu sebesar 64,43 . Terdapat perbedaan yang signifikan antar jenjang usia, dimana semakin bertambah jenjang usianya, maka akan menghasilkan rata-rata skor empati yang semakin tinggi pula. Dijelaskan bahwa rentang usia tersebut merupakan tahap usia dewasa awal yang cenderung memiliki egoisme yang tinggi mengingat kebutuhan akan aktualisasi diri.

4. Berdasarkan kegiatan waktu luang yang dilakukan, penelitian ini menyatakan bahwa kegiatan berkumpul/bermain bersama temannya lebih dominan. Hasil penelitian ini menunjukkan bahwa ratarata nilai skor empati yang memilih untuk berkumpul bersama teman lebih tinggi dari yang menghabisan waktu dengan bermain sosial media yaitu 62,44 . Kondisi ini menunjukkan bahwa empati responden yang memilih untuk berkumpul bersama teman dalam mengisi waktu luangnya lebih tinggi meskipun tidak menunjukkan perbedaan yang signifikan. Hal ini tidak mempengaruhi empati seseorang, namun manusia sebagai makhluk sosial tak dapat hidup sendiri, empati berguna untuk membantu manusia dalam bersosialisasi, serta menjalin relasi yang berkualitas dan baik dengan orang lain.

5. Berdasarkan bahasa yang digunakan dalam kehidupan sehari-hari, penelitian ini menyatakan bahwa mayoritas subjek menggunakan bahasa Indonesia. Hasil penelitian ini berdasarkan bahasa yang digunakan tidak menunjukkan perbedaan yang signifikan dengan ratarata nilai skor empati yang menggunakan Bahasa Indonesia lebih 
tinggi dari bahasa yang lainnya yaitu sebesar 62,25. Kondisi ini menunjukkan bahwa empati tidak dipengaruhi berdasarkan bahasa yang digunakan, namun dengan keseragaman bahasa akan mempermudah proses komunikasi sehingga umpan balik yang diharapkan adalah sikap empati dari pengalaman yang dibagikan.

\section{DAFTAR PUSTAKA}

Ali, H., \& Lilik Purwandi. (2017). Millennial Nusantara Pahami Karakternya, Rebut Simpatinya. Jakarta: PT Gramedia Pustaka Utama.

Arnett, J. J. (2006). Emerging Adulthood: Understanding The New Way ofComing of Age. Dalam J.J. Arnett \& J.L Tanner (Ed). Emerging Adults in America: Coming of Age in the 21st Century. Washington, D.C : American Psychological Association.

Arumi, Mira S., dkk. (2017). Empati Mahasiswa Psikologi. Vol. 1 (2) 78-157. ISSN 2088-7655.

Asih, Yuli Gusti \& Margaretha Maria Shinta Pratiwi. (2010). Perilaku Prososial Ditinjau dari Empati dan Kematangan Emosi. Volume I, No 1, Desember 2010.

Astuti, Yuni Setya. (2014). Hubungan antara empati dengan perilaku prososial pada karang taruna di Desa Jetis, Kecamatan Baki, Kabupaten Sukoharjo. Surakarta: Fakultas Psikologi UMS

Badan Pusat Statistik. (2018). Statistik Gender Tematik: Profil Generasi Milenial Indonesia. Jakarta: BPS.

Badan Pusat Statistik kota Pekanbaru. (2019). Kota Pekanbaru dalam angka 2019. Pekanbaru: BPS Kota Pekanbaru.

Baron, R A., Byrne, D. (2005). Psikologi Sosial Jilid 2. Alih Bahasa: Ratna Djuwita. Edisi kesepuluh. Jakarta: Erlangga.

Bencsik, A., \& Machova, R. (2016). Knowledge Sharing Problems from the Viewpoint of Intergeneration Management. In ICMLG2016 - 4th International Conferenceon Management, Leadership and
Governance: ICMLG2016 (p.42). Academic Conferences andpublishing limited.

Berkup, S. B. (2014). Working With Generations X And Y In Generation Z Period: Management Of Different Generations In Business Life. Mediterranean Journal of Social Sciences.

Bencsik, A., dkk. (2016). $Y$ and $Z$ Generations at Workplaces. Vol. 8, Issue 3, pp. 90 - 106. Journal of Competitiveness.

Bungin, B. (2005). Metodotologi Penelitian Kuantitatif: Komunikasi, Ekonomi, Dan Kebijakan Politik Serta IImu-IImu Sosial Lainnya. Jakarta: Kencana.

Burgon \& Huffner. (2002). Komunikasi Antar Pribadi. London: Sage Publication.

Butarbutar, Ranafika \& Achmat, Fathi. (2018). Gambaran Empati Perawat Dalam Memberikan Asuhan Keperawatan Di Ruang Rawat Inap Rsup H. Adam Malik Medan. Volume 1 Issue 1-2018 TALENTA Conference Series: Tropical Medicine (TM) 1-5.

Carlson, Elwood. (2008). The Lucky Few: Between the Greatest Generation and the Baby Boom. Springer scence : Business Media B. V.

Dolby, N. (2014). The Future of Empathy: Teaching the Millennial Generation. Journal of Collage and Character, 14 (1), 39-44.

Fitriyanti. (2014). Perilaku Empati pada Mahasiswa di Asrama Putri Nusantara Universitas Negeri Gorontalo. Universitas Negeri Gorontalo, Bimbingan dan Konseling. Gorontalo: Fakultas IImu Pendidikan Universitas Negeri Gorontalo.

Goleman, D. 2000. Kecerdasan Emosi Untuk Mencapai Puncak Prestasi. Cetakan ke-1. Jakarta: PT Gramedia Pustaka Utama.

Gustini, Neng. (2017). Empati Kultural pada Mahasiswa. Volume 1, No. 1, Maret 2017: Page 17-34

Hartik, Andi. (2016). 8 Pemuda Perkosa Seorang Siswi SMP di Kota Pasuruan. Retrieved December 21, 2019, from Kompas: 
https://megapolitan.kompas.com/read/2 016/06/25/19323061/8.pemuda.perkos a.seorang.siswi.smp.di.kota.pasuruan.

Hayi, A., Setyowati, E., dan Djunaedi. (2015). Gambaran Empati Dasar Mahasiswa Bimbingan dan Konseling Etnis Batak di DKI Jakarta. Vol 4 No 2 : Jurnal Bimbingan dan Konseling.

Hidayah, A., Martina Sinta K., Mariyono S. (2013). Perbedaan Kemampuan Empati Mahasiswa Keperawatan di Program Studi IImu Keperawatan Fakultas Kedokteran UGM. Vol. 2 | No. 2 | Juni 2013 | Jurnal Pendidikan Kedokteran Indonesia.

Ika, A. (2013). Empati Masyarakat Indonesia Sangat Kurang. Universitas Gajah Mada, Kebudayaan. Yogyakarta: UC UGM.

Juliharti, Depa. (2017). Ironis, Mulai Terkikisnya Belas Kasih dan Rasa Empati Hanya Karena Euforia Medsos. Retrieved Maret 24, 2019, from hipwee: https://www.hipwee.com/opini/mulaiterkikisnya-rasa-empati-karena-mediasosial/.

Kementerian Perencanaan Pembangunan Nasional (Bappenas) dan United Nations Children"s Fund. (2017). Laporan Baseline SDG tentang AnakAnak di Indonesia. Jakarta: BAPPENAS dan UNICEF.

Kompasiana. (2017). Kasus Viona Magdalena dan Pentingnya Simpati serta Empati dalam Home Care Profesional. Retrieved December 21, 2019, from kompasiana-homecare24: https://www.kompasiana.com/homecar e24/593ae26ecaf7db03ec30a6d3/kasu s-viona-magdalena-dan-pentingnyasimpati-serta-empati-dalam-home-careprofesional.

Konrath, S., O'Brien, E., \& Hsing, C. (2011). Changes in Dispositional Empathy in American Collage Students Over Time: A Meta Analysis. Personality and Social Psychology Journal, 15 (2), 180-198.

Lyons, S. (2004). An exploration of generational values in life and at work. ProQuest Dissertations and Theses, 441-441.
Listiyandini, R. A., Sulaiman, S., Sidik, E. H., Larasati, I., Priatni, M. R., Meysarani, S. (2017). Empathy Among Indonesian Medical Students: A Crosssectional Study. Universitas YARSI, Fakultas Psikologi. Jakarta: Universitas YARSI.

Metz, A. L. (2014). Back to Nature: The Impact of Nature Relatedness on Empathy and Narcissism in the Millennial Generation. James Madison University, Psychology. Harrisonburg: Educational Specialist.

Nashori, H. F. (2008). Psikologi Sosial Islami. Bandung: PT Refika Aditama.

Nugroho, Kevin M., Taufik, F.P., George,N.T. (2016). Gambaran Empati Pada Mahasiswa Fakultas Kedokteran Universitas Sam Ratulangi Angkatan 2012. Jurnal e-Biomedik (eBm), Volume 4, Nomor 1, Januari-Juni 2016.

Patty, Rahmat Rahman. (2015). Siswi SMP Dikeroyok Temannya, Orangtua Lapor Polisi. Retrieved December 21, 2019, from kompas

https://regional.kompas.com/read/2015/ 03/26/19303611/Siswi.SMP.Dikeroyok. Temannya.Orangtua.Lapor.Polisi

Putra, Yanuar Surya. (2016). Theoritical Review : Teori Perbedaan Generasi. Among Makarti Vol.9 No.18, Desember 2016.

Rosyadi , Ajeng Etika Anggun (2017). Empati dengan Perilaku Altruisme Mahasiswa. Sekolah Tinggi IImu Kesehatan Insan Cendekia. Jombang: Ilmu Keperawatan.

Runtuwarow, S., F. Pasiak, T., dan R. Ticoalu. (2017). Gambaran empati pada mahasiswa Fakultas Kedokteran Universitas Sam Ratulangi angkatan 2011. Jurnal e-Biomedik (eBM), Vol. 5, No. 1, Januari-Juni 2017.

Saumi, Annisa. (2019). Kasus Bunuh Diri dan Hilangnya Empati Warga. Retrieved December 21, 2019, from alinea.id: https://www.alinea.id/gayahidup/kasus-bunuh-diri-dan-hilangnyaempati-warga.

Sejiwa. (2007). Bullying: Panduan bagi Orangtua dan Guru. Mengatasi Kekerasan di Sekolah dan Lingkungan. Jakarta:Grasindo. 
Stafford, D., \& Griffis, H. (2008). A review of millennial generation characteristics and military workforce implications. Center for Naval Analysis, May.viewdoc/download?doi=10.1.1.148 $.7496 \&$ rep $=$ rep $1 \&$ type $=p d f$

Sukmawati, Fitri. (2017). Bulliying di Media Sosial: Potret Memudarnya Empati. Vol. 11 No.1, 2017.

Tanjung, Hasbullah. (2019) Jadi Korban Bullying, Siswi SMP Di Pekanbaru Mengurung Diri. Retrieved Maret 24, 2019, from Riau Online pekanbaru/read/2019/03/18/jadikorban-bullyng-siswi-smp-dipekanbaru-mengurung-diri.

Tanjung, Idon. (2019). Remaja di Riau Bunuh Pacar Gunakan Cangkul Karena Menolak Berhubungan Badan. Retrieved December 21, 2019, from kompas

https://regional.kompas.com/read/2019/ 08/19/13253301/remaja-di-riau-bunuhpacar-gunakan-cangkul-karenamenolak-berhubungan-badan.

Taufik. (2012). Empati Pendekatan Psikologi Sosial. Jakarta: Raja grafindo. Tri Dayakisni \& Hudaniah (2009). Psikologi Sosial. Malang: UMM Press.

Twenge, J. M. (2006). Generation Me: Why Today's YoungAmericans Are
More Confident, Assertive, Entitledand More Miserable Than Ever Before. New York: Free Press

Viorensika, S \& Suleeman, J. (2013). Gambaran empati pada mahasiswa psikologi jenjang sarjana. Skripsi tidak dipublikasikan. Depok. Program Studi Sarjana Reguler Fakultas Psikologi Universitas Indonesia.

Wardhani, H. A. (2018). Empati di Tinjau dari Pola Asuh Orang Tua dan Jenis Kelamin. Universitas Muhammadiyah Surakarta, Psikologi. Surakarta: Fakultas Psikologi UMS.

Yusra, M.S., Awaluddin T., \& Happy K.M. (2015). Empati dasar mahasiswa BK berdasarkan tipe kepribadian introvert dan ekstrovert angkatan 2011 di Universitas Negeri Jakarta. Vol. 4 No.2: Insight: Jurnal Bimbingan dan Konseling.

Zahro. A, A Awalya, MTS Haratati. (2018). Meningkatkan Empai melalui Layanan Penguasaan Konten dengan Teknik Role Playing. Indonesian Journal of Guidance and Counseling: Theory and Application 7 (2), 1-6. 
Volume 1, No.1, Juni 2021 